\title{
Improved Traditional Medicines in Mali
}

\author{
Merlin Willcox, BA, BM, BCh, MRCGP, ${ }^{1,2}$ Rokia Sanogo, PhD, ${ }^{3,4}$ Chiaka Diakite, MD, ${ }^{3}$ \\ Sergio Giani, PharmD, ${ }^{5}$ Berit Smestad Paulsen, PhD, ${ }^{6}$ and Drissa Diallo, PhD ${ }^{3,4}$
}
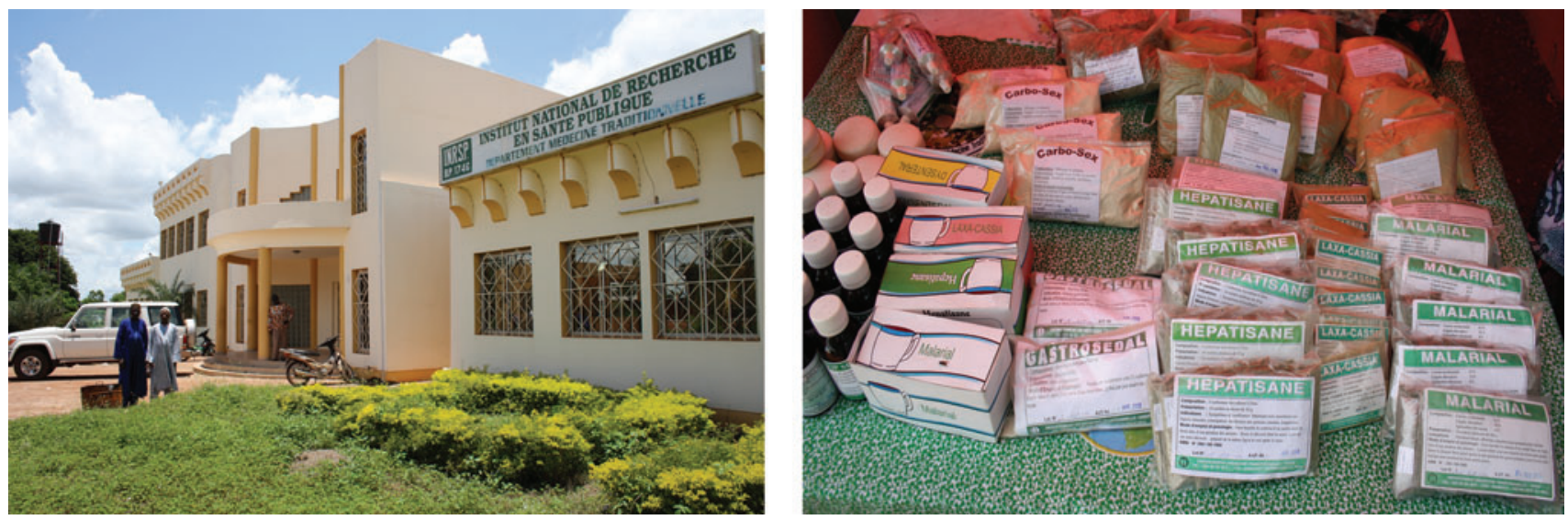

Left: The Department for Traditional Medicine, Bamako, Mali. Photo (c) Merlin Willcox. Right: Médicaments Traditionnels Améliorés for sale on a stall (Bamako, Mali). Photo @ Merlin Willcox. Color images available online at www.liebertonline.com/acm

\section{Introduction}

M ALI IS UNUSUAL IN ENJOYING a high level of government support for research and development of traditional medicines. The Department for Traditional Medicine, within the National Institute for Research on Public Health (part of the Ministry of Health), was founded in 1968 (originally as the National Institute of Phytotherapy and Traditional Medicine), and in 2005 moved to new purpose-built premises. Since 1979, one of its aims has been the development of standardized "Médicaments Traditionnels Améliorés" (MTAs, or improved traditional medicines).

The "improvement" lies in the pharmacologic evidence of safety and efficacy, the standardized dose and quality control. In order to obtain marketing authorization, a dossier of information on the remedy's safety and efficacy must be submitted to the Commission Nationale d'Autorisation de Mise sur le Marché of the Ministry of Health. Malian regulations categorize traditional medicines as shown in Table $1 .{ }^{1}$ The requirements for the dossier vary according to the category (Table 2). Most MTAs are of category 2, for which clinical trials are not an absolute requirement.
Since 1990, MTAs have been included on the Essential Drugs List of Mali, are included in the Malian National Formulary $^{2}$ alongside conventional drugs, and are distributed through pharmacies. There are currently seven approved MTAs in the formulary ${ }^{2}$ (Table 3), and more are under development. They are intended to be a safe and effective, but locally produced and less expensive, alternative to imported medicines. This article is a systematic review of the preclinical and clinical literature on the safety and efficacy of these medicines. Voucher specimens of all these plants have been deposited at the herbarium of the Département de Médecine Traditionnelle (Table 3). Monographs for all these plants are available online at: http:// portal.ics.trieste.it/MAPs/MedicinalPlants_Country.aspx\# Mali

\section{Balembo syrup (Crossopteryx febrifuga)}

Crossopteryx febrifuga Benth. (Rubiaceae) is a small tree 5-6 $\mathrm{m}$ high with small round fruit, which become black when ripe (Fig. 1). They are rich in flavonoids and polysaccharides. The seeds have anti-inflammatory properties. ${ }^{3}$

\footnotetext{
${ }^{1}$ Department of Primary Health Care, University of Oxford, Oxford, UK.

${ }^{2}$ Research Initiative on Traditional Antimalarial Methods, Oxford, UK.

${ }^{3}$ Département de Médecine Traditionnelle, Institut National de Recherche en Santé Publique, Bamako, Mali.

${ }^{4}$ Faculté de Médecine, Pharmacie et Odonto-Stomatologie, Université de Bamako, Mali.

${ }^{5}$ Aidemet ONG, Bamako, Mali.

${ }^{6}$ School of Pharmacy, University of Oslo, Oslo, Norway.
} 
Table 1. Categories of Traditional Medicines in MaLian Law ${ }^{1}$

\begin{tabular}{lc}
\hline Category & Description \\
\hline 1 & $\begin{array}{c}\text { Traditional medicine prepared by a traditional } \\
\text { health practitioner for an individual patient with } \\
\text { fresh or dried raw materials, with a short shelf } \\
\text { life }\end{array}$ \\
& $\begin{array}{c}\text { Traditional medicine currently used in the } \\
\text { community, prepared in advance, and composed } \\
\text { of crude raw materials }\end{array}$ \\
3 & $\begin{array}{c}\text { Standardized extracts prepared in advance } \\
\text { following scientific research } \\
\text { Molecules purified from traditional medicines } \\
\text { following scientific research }\end{array}$ \\
\hline
\end{tabular}

The fruits are boiled in water to produce a syrup, which was the most effective of several antitussive remedies tested, ${ }^{4}$ and is nontoxic when given orally. ${ }^{5}$ There was very low toxicity at the dose of $30 \mathrm{~g} / \mathrm{kg}$ administrated orally in mice.* In the model of cough in guinea pigs provoked by nebulized citric acid, it reduced the number of coughs by $63 \%$ at a dose of $250 \mathrm{mg} / \mathrm{kg}$, and by $77 \%$ at a dose of $1 \mathrm{~g} / \mathrm{kg}$ (compared to $76 \%$ by codeine at $10 \mathrm{mg} / \mathrm{kg}$ ). The lower dose of $50 \mathrm{mg} / \mathrm{kg}$ was not effective. ${ }^{6}$ The remedy (at an oral dose of $1 \mathrm{~g} / \mathrm{kg}$ ) also reduced antigen-induced bronchoconstriction in guinea pigs by $54 \%$, compared to a reduction of $78 \%$ by disodium cromoglicate (at a dose of $10 \mathrm{mg} / \mathrm{kg}$ ). However, it had no effect on histamine-induced bronchoconstriction, and aqueous extracts were not active against bacteria that commonly cause respiratory infections. ${ }^{7}$ A clinical trial in 32 patients with cough showed improvement after 7 days, ${ }^{*}$ and a sedative effect. ${ }^{5}$ Now Balembo syrup is the most frequently prescribed MTA; it is prescribed by up to $76 \%$ of biomedical health workers in Mali, and is also the most widely known by patients. ${ }^{8}$

\section{Dysentéral (Euphorbia hirta)}

Euphorbia hirta (Euphorbiaceae) is a common pantropical weed (Fig. 2), widely used in many African countries for the treatment of dysentery. ${ }^{9-11}$ E. hirta is active in vitro against several different microorganisms that cause diarrhea or dysentery (Table 4). All studies show a good activity against Entamoeba histolytica, and the whole plant is more active than the leaves alone. ${ }^{12}$ There are conflicting results for Escherichia coli: One study from India shows good activity, ${ }^{13}$ whereas two from Africa show minimal or no activity. ${ }^{14,15}$

Furthermore, E. hirta contains tannins (such as ellagic acid and gallic acid) and flavonoids (such as quercitin), which have antidiarrheal and antiamoebic activity. ${ }^{12,16}$ The water extract has spasmolytic activity on guinea-pig ileum ${ }^{9,17}$ and reduces castor-oil-induced diarrhea in mice. ${ }^{18}$

The pharmacology, chemistry, and toxicology of the plant have been studied extensively.,19 The aerial parts contain shikimic acid and the roots and sap contain phorbol esters, which are potentially carcinogenic, ${ }^{5,9}$ although in an experi-

\footnotetext{
${ }^{*}$ Kodio A. Contribution to the study of the consumption of cough syrups in the Republic of Mali: Evaluation of the need and improvement of Balembo syrup [in French; PharmD thesis]. Bamako, Mali: Ecole Nationale de Médecine et de Pharmacie (ENMP), 1986.
}

Table 2. Components of the Brochure for Requesting a Marketing Authorization for a Traditional Herbal Medicine in Mali ${ }^{1}$

Section Detailed components

1. Covering letter Addressed to the Ministry of Health and including the name and address of the manufacturer

2. Administrative - Registration document of the dossier manufacturer

- Memoranda of understanding between the manufacturer and a research institution ${ }^{\text {a }}$

3. Samples 10 samples as sold

4. Fees Receipt for registration fees

5. Pharmaceutical - Complete monograph(s) of the dossier $^{b}$ component plant(s)

- Method and stages of preparation and production

- Expert report on Good Manufacturing Practices

6. Expert analytical - Quality control method for raw report materials

- Results of stability and quality control tests of raw materials and excipients

- Method and results of quality control during production

- Results of quality control of the finished product

- Results of stability tests of the finished product

7. Pharmacology - Pharmacodynamic data and toxicology - Results of acute and subchronic dossier $^{c} \quad$ toxicity tests

- Literature review of pharmacology and toxicology

- Expert report on the tests carried out

8. Clinical dossier ${ }^{\mathrm{c}}$ - Ethical approval for clinical trials

- Clinical trial protocol following standard methods (phase I and II)

- Results of clinical trials

- Expert report on clinical trials carried out

9. Expert report on - Evidence of long experience of use of traditional use the medicine in its current or traditional form (minimum 20 years)

- Detailed presentation of known toxicological risks

- Risks of incorrect use of the medicine

- Risks of physical or psychologic dependence

\footnotetext{
${ }^{\mathrm{a}}$ For medicines of categories 3 and 4 .

${ }^{\mathrm{b}}$ For medicines of categories 2 and 3 .

${ }^{c}$ For medicines of category 3.
}

mental model E. hirta ether extracts had almost no tumorpromoting activity compared to other Euphorbia species. ${ }^{20}$ Roots should not be used, and it is said that aerial parts should be dried, which removes the carcinogenic effect. ${ }^{5, \dagger}$ However, one study found that drying diminishes the in vitro

${ }^{\dagger}$ Dolo A. Contribution to the study of the toxicology of Malian medicinal plants [French; PharmD thesis], Bamako, Mali:Ecole Nationale de Médecine et de Pharmacie (ENMP), 1991. 


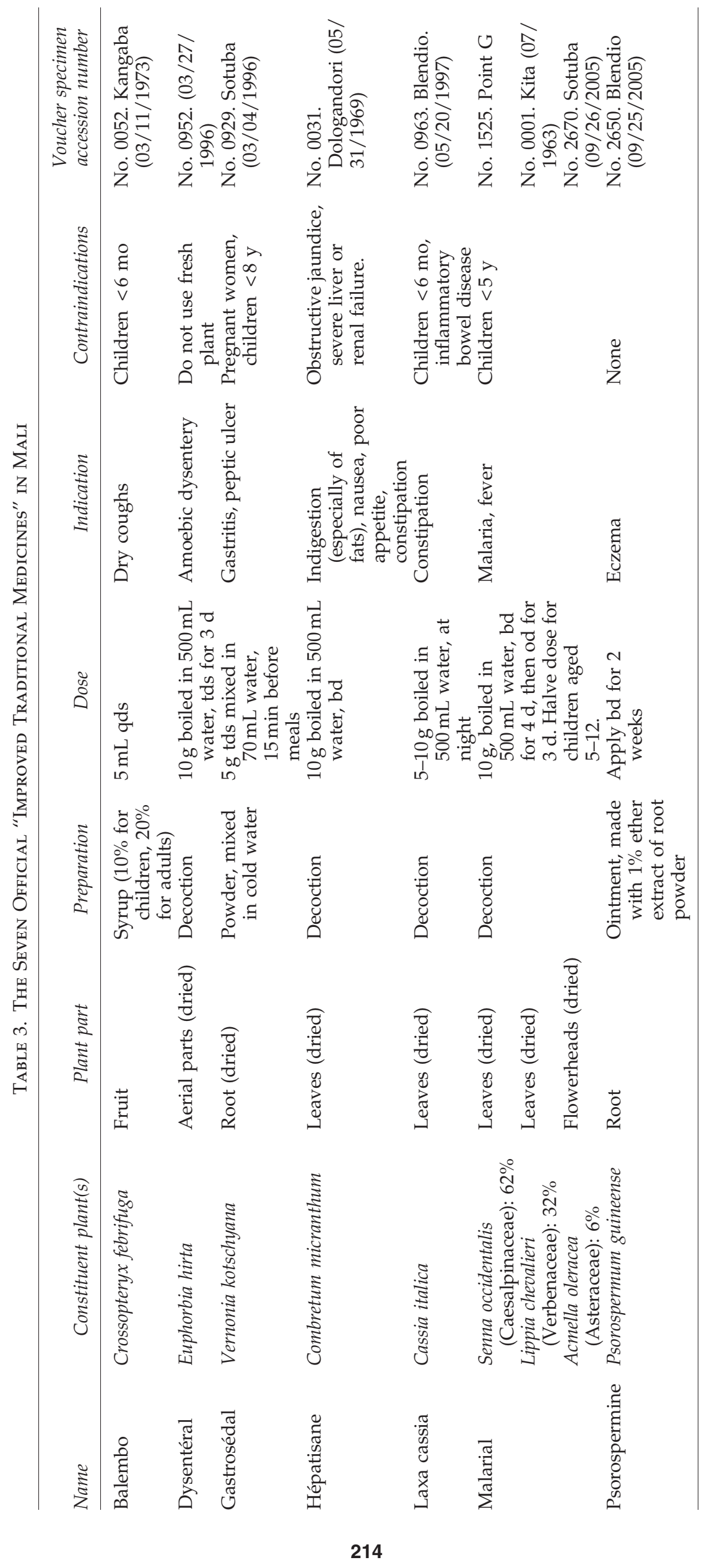




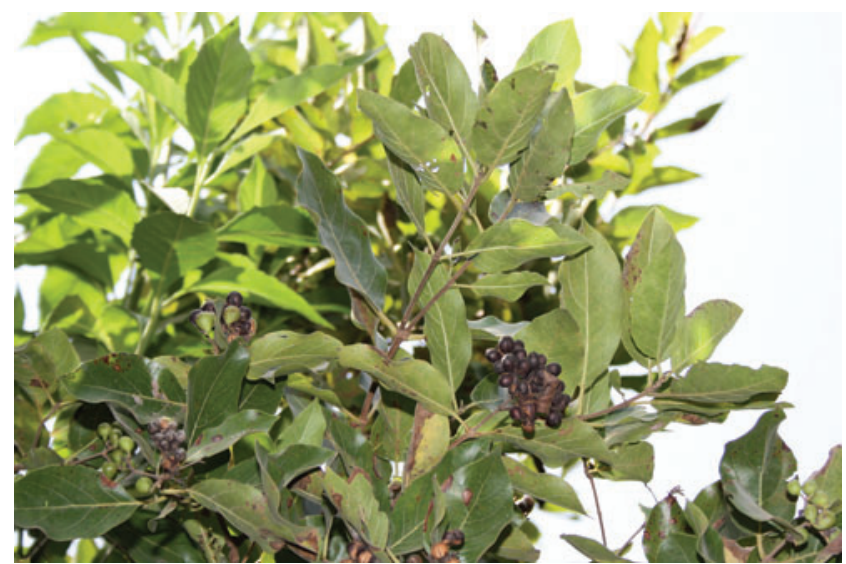

FIG. 1. Crossopteryx febrifuga (Rubiaceae) black fruits are used to make a cough syrup. Photo (c) Merlin Willcox. Color images available online at www.liebertonline.com/acm

antiamoebic activity. ${ }^{21}$ Rats fed up to $5 \%$ powdered whole plant for up to 97 days in their diet showed no symptoms of poisoning, and no gross pathology on autopsy, ${ }^{9}$ although hypotensive effects have been found in cats and dogs. ${ }^{17} \mathrm{~A}$ daily dose of alcohol extract (corresponding to $3 \mathrm{~g} / \mathrm{kg}$ of dried plant) was tested in rats for up to 27 days with no observed toxic effects. ${ }^{19}$ Aqueous extracts produced no toxicity when given orally to rats at doses of up to $30 \mathrm{~g} / \mathrm{kg}$.

Uncontrolled clinical trials of several different extracts have been carried out. The lyophilized decoction (three doses of $10 \mathrm{~g}$ ) was effective in treating a series of 10 patients with amoebic dysentery in Senegal. ${ }^{9}$ A tincture of fresh aerial

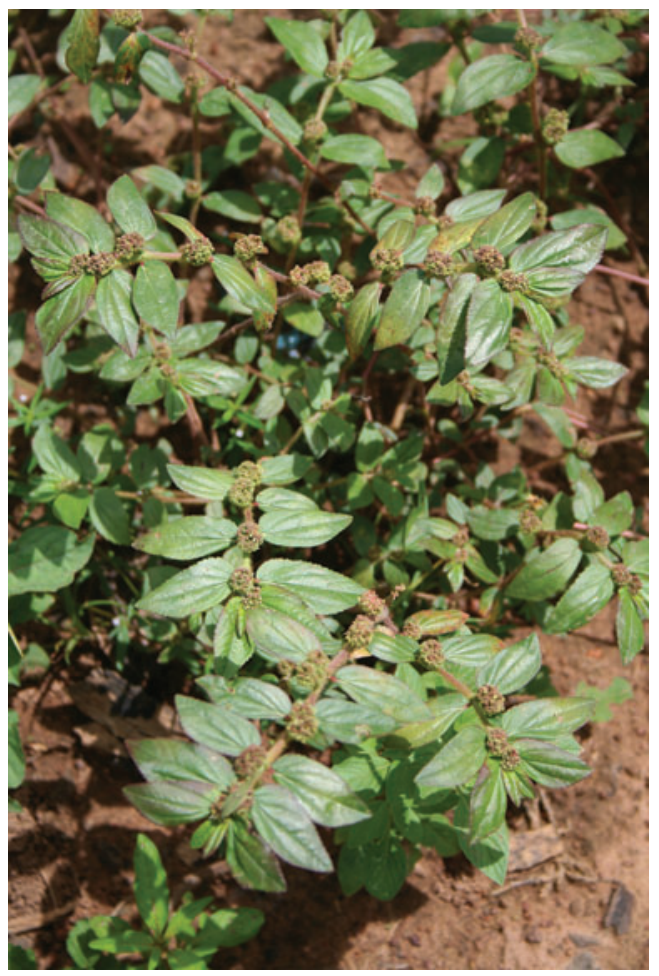

FIG. 2. Euphorbia hirta (Euphorbiaceae) dried aerial parts are decocted to treat dysentery. Photo (c) Merlin Willcox. Color images available online at www.liebertonline.com/acm parts (1:2) was tested in a series of 40 cases of acute amoebic dysentery or diarrhea at the Centre Muraz, Bobo-Dioulasso, Burkina Faso. ${ }^{19}$ Thirty-eight (38) patients were cured with a dose of $10 \mathrm{~mL}$ four times daily for 9 days, with normalization of the stools within 2-6 days, and no reported adverse effects. ${ }^{19}$ A second case series (using the same extract in tablet form, with a daily dose of $7.2 \mathrm{~g}$ of dried plant material, for 8 days) resulted in 125 cures out of 150 patients treated. ${ }^{22}$ In this series, the adverse effects reported were 12 cases of hypotension, two of nausea/vomiting, and one allergic reaction, none of which were severe. An unpublished clinical trial was conducted in Mali of "Dysentéral" treatment (according to the dosage in Table 3). Trophozoites of E. histolytica disappeared from the stool after 2 days, which was equivalent to treatment with metronidazole. ${ }^{5}$

\section{Gastrosédal (Vernonia kotschyana)}

Vernonia kotschyana Sch. Bip. Ex Walp. (Asteraceae) is a herbaceous plant that grows to a height of about $1 \mathrm{~m}$ (Fig. 3). Its thick roots are powdered and used (often mixed with hot water) for indigestion and stomach pains in Mali and Nigeria. ${ }^{23,24}$ The roots contain steroid glycosides (vernoniosides D1-3 and F1-2) , 25 and different types of polysaccharides such as inulin, pectins, and arabinogalactans, some of which have anti-inflammatory and immunomodulatory properties. $^{24,26}$

Aqueous extracts are effective at preventing ethanol and stress-induced gastric ulcers in rats, equivalent to $50 \mathrm{mg} / \mathrm{kg}$ of ranitidine. ${ }^{27}$ Two (2) uncontrolled clinical trials have been carried out in patients with gastric ulcers. In the first, $80 \%$ (of 47 patients) reported symptomatic improvement. ${ }^{28}$ In the second, 16 patients were followed up after 30 days of taking $V$. kotschyana root tablets ( $6 \mathrm{~g}$ daily). Half of the patients had symptomatic improvement, and the ulcers had healed in 6 patients. $^{24, \text { * }}$

\section{Hépatisane (Combretum micranthum)}

Combretum micranthum (Combretaceae) is a small tree, common on the poor soil of the Sahel savannah. Twigs with leaves are commonly sold in markets by the name of kinkéliba. ${ }^{23}$ Like other Combretum species, it has characteristic four-winged fruit (Fig. 4). Chemical constituents include potassium nitrate, flavonoids (such as vitexin), organic acids, tannins, coumarins, sterols, terpenoids, carbohydrates (inositol, mannitol, sorbitol), and alkaloids (choline, stachydrine). ${ }^{5,23}$

It has a wide variety of medicinal uses in West Africa, particularly as a cholagogue. In 1891, a French doctor in Gambia observed its efficacious use in the treatment of fièrres bilieuses hématuriques (bilious fevers with hematuria). ${ }^{23}$ The leaves are often used to prepare a refreshing tea, but this is also used for jaundice and hepatitis. ${ }^{11,29}$ It was added to the French pharmacopoeia in 1937, and to the African Pharmacopoeia in $1985 .^{23}$ In Mali, patients with nonobstructive jaundice have been treated with Hépatisane and their bilirubin and transaminases have returned to normal within 2-3 weeks of starting the treatment. ${ }^{5}$ About 50

Toure IAK. Evaluation of the therapeutic efficacy of an improved traditional recipe (Gastrosédal) in the treatment of gastritis [in French; MD thesis]. Bamako, Mali: Faculté de Médecine, Pharmacie et Odonto-Stomatologie, Universite de Bamako, 1989. 
Table 4. In Vitro Activities of Euphorbia hirta Against Microorganisms Causing Diarrhea

\begin{tabular}{|c|c|c|c|c|c|c|}
\hline Target organism & Part & $\begin{array}{l}\text { Fresh } \\
\text { or dried? }\end{array}$ & $\begin{array}{c}\text { Type } \\
\text { of extract }\end{array}$ & $\begin{array}{c}\text { Active concentration } \\
(\mathrm{g} / 100 \mathrm{~mL})\end{array}$ & $\begin{array}{c}\text { MIC } \\
(m g / m L)\end{array}$ & Ref \\
\hline \multirow[t]{4}{*}{ Entamoeba histolytica } & WP & Fresh & Aqueous decoction & 20 & & 20 \\
\hline & WP & Dried & Aqueous decoction & 11 & & 20 \\
\hline & $\mathrm{L}$ & Fresh & Aqueous maceration & 16 & 0.250 & 13 \\
\hline & WP & Fresh & Aqueous maceration & 20 & 0.031 & 13 \\
\hline \multirow[t]{2}{*}{ Escherichia coli } & $\mathrm{L}$ & Dried & Ethanol $95 \%$ & 8 & 58.0 & 16 \\
\hline & $\mathrm{AP}$ & Dried & Ethanol & & 0.189 & 14 \\
\hline Salmonella typhimurium & WP & Dried & Methanol & 10 & & a \\
\hline Shigella dysenteriae & FL & & Methanol & 0.1 .56 & 0.2 & $\mathrm{~b}$ \\
\hline Shigella flexneri & FL & & Methanol & 0.1 .56 & 0.1 & $\mathrm{~b}$ \\
\hline Polio virus & WP & Dried & Ethanol $80 \%$ & 2.5 & & 15 \\
\hline Coxsackie virus & WP & Dried & Ethanol $80 \%$ & 2.5 & & 15 \\
\hline Herpes virus & WP & Dried & Ethanol $80 \%$ & 2.5 & & 15 \\
\hline
\end{tabular}

a Parekh J, Jadeja D, Chanda S. Efficacy of aqueous and methanol extracts of some medicinal plants for potential antibacterial activity. Turk J Biol 2005;29:203-210.

${ }^{b}$ Vijaya K, Ananthan S, Nalini R. Antibacterial effect of theaflavin, polyphenon 60 (Camellia sinensis) and Euphorbia hirta on Shigella spp.: A cell culture study. J Ethnopharmacol 1995;49:115-118.

MIC, minimum inhibitory concentration; AP, aerial parts; FL, flowers; L, leaves; WP, whole plant.

asymptomatic patients with chronic viral hepatitis B have been treated with Hépatisane in a clinical trial, but there was no clearance of the hepatitis B surface antigen (J. Falquet, personal communication). However, the herbal treatment was well-tolerated, there were no adverse effects, and compliance was good. Further clinical trials are needed to determine whether this treatment helps patients with symptomatic hepatitis, or whether it helps to prevent longterm consequences of chronic viral hepatitis.

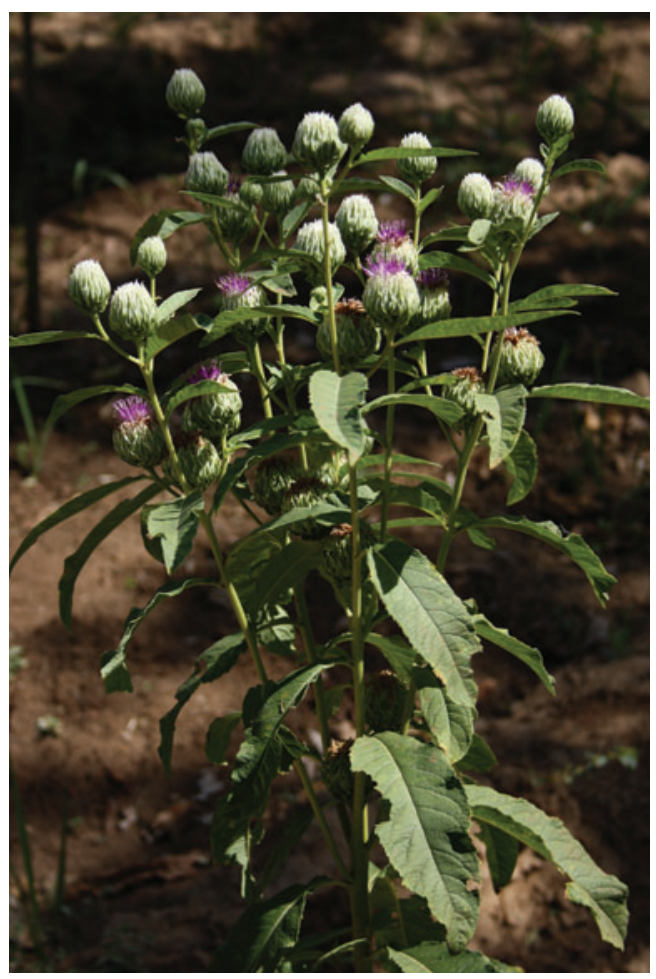

FIG. 3. Vernonia kotschyana Sch. Bip. Ex Walp. (Asteraceae) rhizome is effective against indigestion and gastric ulcers. Photo (c) Merlin Willcox. Color images available online at www.liebertonline.com/acm

\section{Laxa Cassia (Senna italica)}

Senna italica Mill (synonym = Cassia italica, Caesalpinaceae) is a shrub widespread in the dry regions of Africa, and is the local equivalent of senna (which in Europe is made from Cassia senna and Cassia angustifolia). Research has confirmed that its chemical composition is the same as that of C. angustifolia. ${ }^{9}$ The leaves and fruit are rich in sennosides (anthraquinone glycosides), ${ }^{30}$ which are broken down in the colon and cecum by the gut flora to the active rhein anthrone.

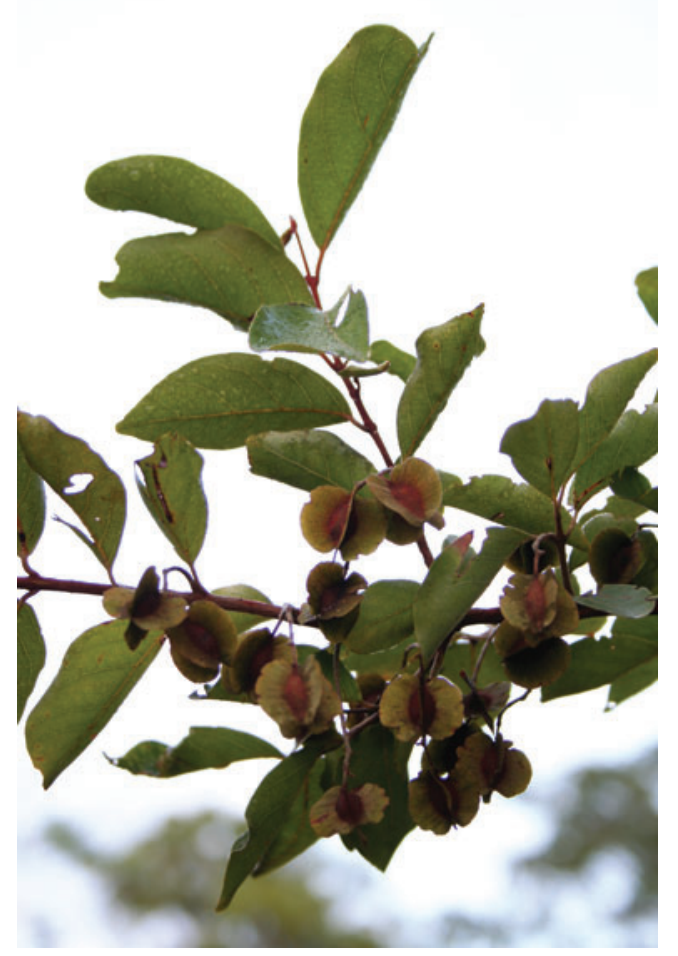

FIG. 4. Combretum micranthum (Combretaceae) leaf decoction is a popular beverage and aids digestion.

Photo (c) Merlin Willcox. Color images available online at www.liebertonline.com/acm 
This stimulates peristalsis. ${ }^{31}$ A common side-effect of overstimulation is colic; this can be reduced by using dry rather than fresh plant material. ${ }^{9}$

Constipation is surprisingly common in Malian villages, attributable to insufficient fiber in the diet (which often consists of little more than maize-meal gruel) and insufficient water intake. As everywhere, it is important to remember that dietary advice (increasing fiber intake, and water intake) is the first-line treatment, and laxatives are a second-line treatment to be used only when absolutely necessary, because of the risk of side-effects. However, it is very sensible for African countries to manufacture their own senna from local plants, rather than to import European senna at a higher price.

\section{Malarial}

"Malarial" was first formulated by Professor Mamadou Koumaré, Professor of Pharmacognosy, former Director of the Department for Traditional Medicine, and President of the Société Malienne de Phytothérapie. It is based on a recipe used in his family, and is now produced as a standardized phytomedicine (Table 3). Senna occidentalis (L.) Link. (synonymous with Cassia occidentalis, Caesalpinaceae) is a pantropical plant (Fig. 5) widely used for the treatment of malaria $^{32}$ and is active in vitro against malaria parasites. ${ }^{33}$ Lippia chevalieri Mold. (Verbenaceae) is an aromatic herb that is used in West Africa to flavor tea and treat fevers ${ }^{34}$ (Fig. 6). Acmella oleracea (L.) R.K.Jansen (synonymous with Spilanthes oleracea L., Asteraceae) is a sprawling plant with yellow flowers that have a variety of uses in traditional medicine, including as a local anaesthetic for toothache, and as an

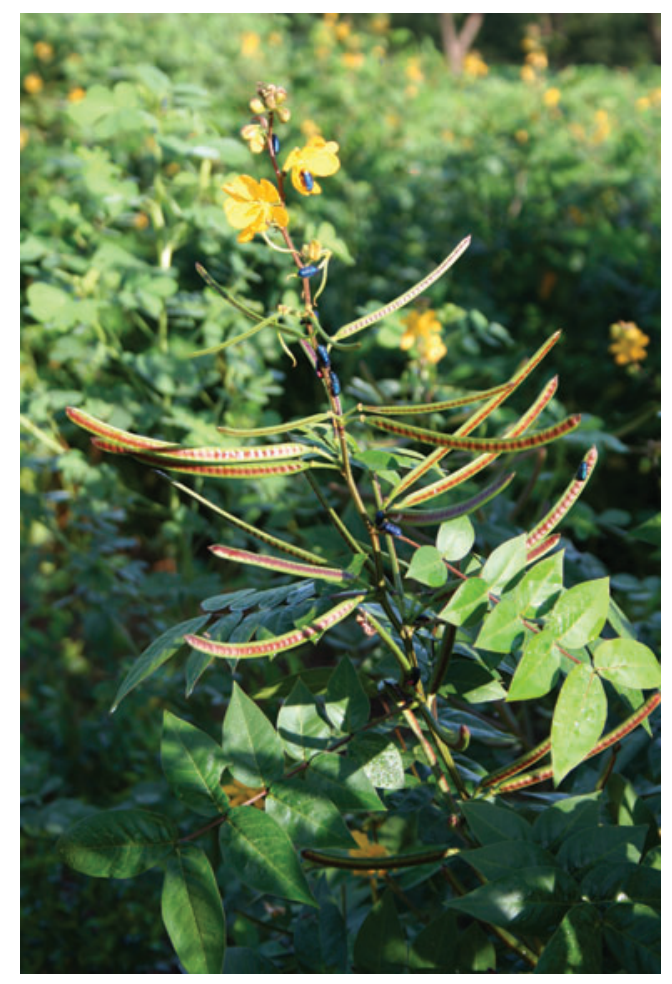

FIG. 5. Cassia occidentalis (Caesalpinaceae) leaves are the major constituent of "Malarial." Photo (c) Merlin Willcox. Color images available online at www.liebertonline.com/acm

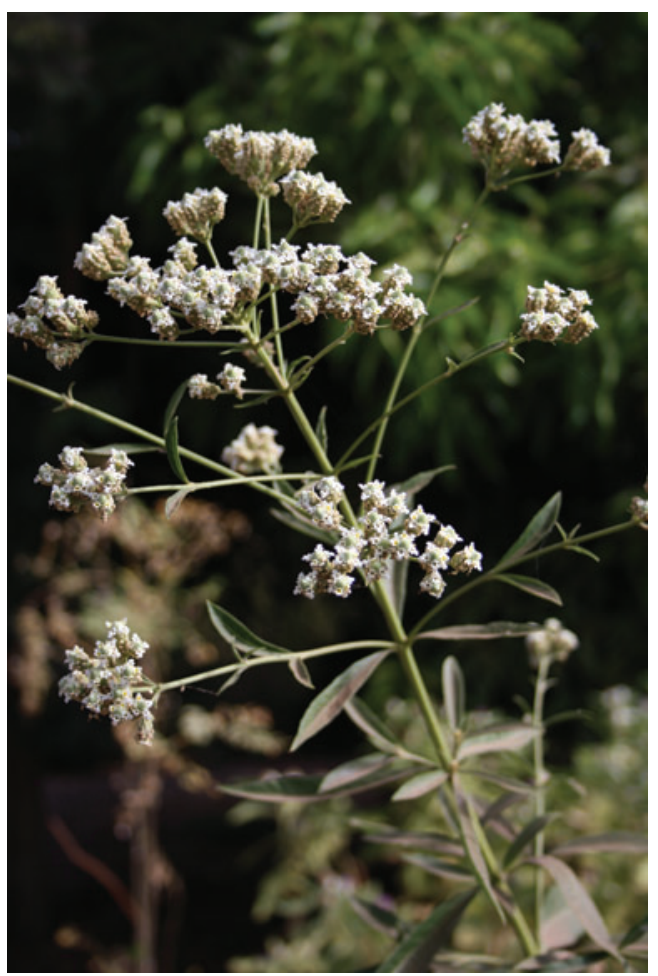

FIG. 6. Lippia chevalieri Mold. (Verbenaceae) leaves are the second constituent of "Malarial" and are mainly used to add a pleasant flavor. Photo (c) Merlin Willcox. Color images available online at www.liebertonline.com/acm

antipyretic (Fig. 7). They contain spilanthol, which is effective against Plasmodium falciparum. "Malarial" was evaluated against malaria parasites in vitro and in mice. It was not very active in vitro (IC50 $=470-600 \mu \mathrm{g} / \mathrm{mL}$ ) but prolonged the survival of malaria-infected mice by 2-3 days compared to the untreated controls. ${ }^{36}$ It was also nontoxic to mice.

Three (3) clinical studies were carried out to evaluate the safety and efficacy of Malarial. The first took place in Baguineda in 1984-1985. The second was a randomized controlled trial comparing it to chloroquine. ${ }^{37,38}$ There were 53 patients included, of whom 36 were randomized to Malarial and 17 to chloroquine. Follow-up to day 21 was completed by $75 \%$ of the Malarial group, and $59 \%$ of the chloroquine group. Fever clearance was similar in both groups, but parasite clearance was better in the chloroquine group. Malarial was better tolerated than chloroquine. It was felt that the amount of Acmella oleracea (4\%) present in this formulation of Malarial was insufficient for a truly effective schizonticidal activity.

It was therefore decided to increase the amount of Acmella oleracea in Malarial to $6 \%$, and this was tested in an observational cohort study on patients with uncomplicated malaria. Thirty (30) patients were included, aged 5 years or above, with a temperature of $>37.5^{\circ} \mathrm{C}$ and a parasitemia of $>3000 / \mathrm{mcl}$ P. falciparum. There was no control group. Parasitemia declined and symptoms improved. Parasitemia at day 7 remained higher in patients aged 8-19 than in older

"Doumbia S. Study of antimalarial plants in Mali [in French; Pharm D thesis]. Bamako, Mali: Faculté de Médecine, Pharmacie et Odonto-Stomatologie, Université de Bamako, 1997. 


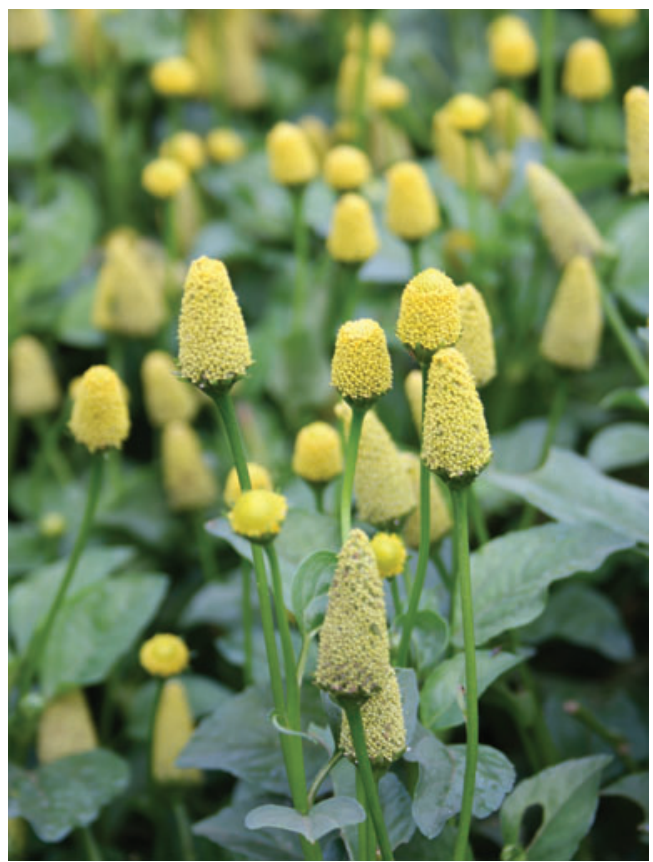

FIG. 7. Spilanthes oleracea (= Acmella oleracea), Asteraceae. Flowerheads are an antimalarial component of "Malarial." Photo (c) Merlin Willcox. Color images available online at www.liebertonline.com/acm

patients. This suggests that patient immunity was playing a role in clearing the parasites.

Research in Mali has been ongoing to produce a new MTA for malaria that is more effective than Malarial, which is the least frequently used MTA. ${ }^{9}$ Argemone mexicana decoction has been selected ${ }^{39}$ and has already undergone clinical trials. ${ }^{40-43}$ It is anticipated that it will soon be approved as a recommended MTA for malaria.

\section{Psorospermine (Psorospermum guineense)}

Psorospermum guineense Hochr. (synonym=Vismia guineensis (L.) Choisy, Hypericaceae) is a West African shrub (Fig. 8). A decoction of its bark, roots, or branches with leaves is widely used for skin conditions such as eczema, psoriasis, ${ }^{\S}$ scabies, cold sores, and leprosy. ${ }^{23}$ It contains tannins, anthraquinones, and xanthones. A dichloromethane extract of root bark is active against the intracellular forms of Leishmania major. $^{44}$

A double-blind, randomized, controlled clinical trial was conducted in Mali comparing "Psorospermine" (60 patients) with shea butter (50 patients) for the treatment of eczema in patients age 3 years and above." It was applied twice daily after washing with soapy water. After 15 days, the treatment failure rate was $18 \%$ in the Psorospermine group, compared

${ }^{\S}$ Diarra II. Contribution to the study of skin diseases and their traditional treatments in Mali [in French; PharmD thesis] Bamako, Mali: Ecole Nationale de Médecine et de Pharmacie au Mali, University of Bamako, 1990.

"Traoré B. Contribution to research on a traditional treatment for eczema: Preliminary study on the feasibility of a clinical protocol [in French; MD thesis]. Bamako, Mali: Faculté de Médecine, Pharmacologie et Odonto-Stomatologie, Université de Bamako, 1995.

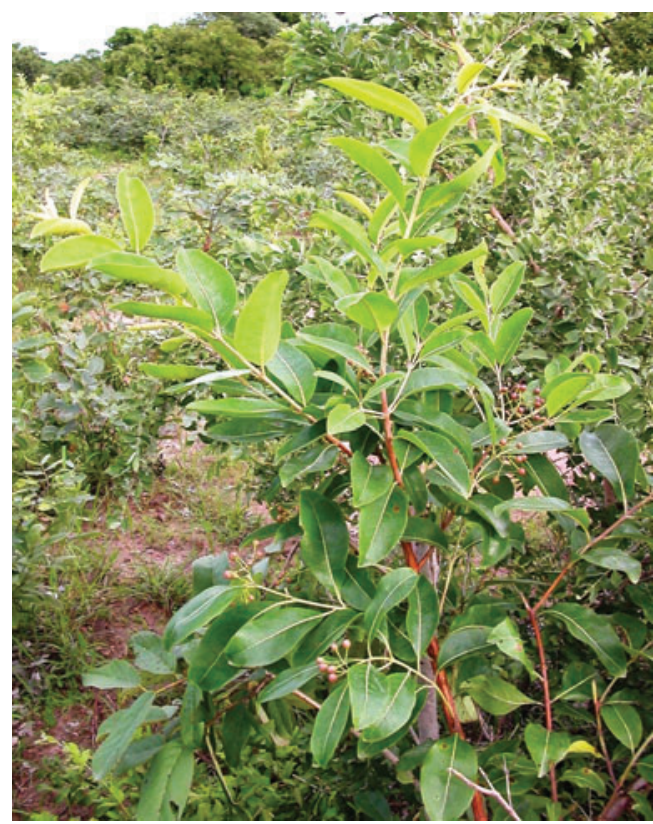

FIG. 8. Psorospermum guineense root extract is used to make an ointment for eczema. Photo, printed with permission, by (C) Dr. Sergio Giani. Color images available online at www .liebertonline.com/acm

to $86 \%$ in the shea butter group $(p<0.0001)$. It was more effective for acute than for chronic eczema $(12 \%$ and $33 \%$ of treatment failures, respectively). It was more effective than shea butter for the different symptoms of eczema: pruritus, erythema, vesicles, exudation, and lichenification. Eightytwo percent $(82 \%)$ of the patients treated with Psorospermine rated it as good or excellent, compared to $14 \%$ of patients treated with shea butter." Shea butter, widely used in cosmetics as a moisturizer, salve, or lotion, comes from the nut of the African shea tree (Vitellaria paradoxa), and the English name is derived from the name of the tree in the Malian language Bambara (sisun).

\section{Discussion}

The first advantage of "improved phytomedicines" is that they can be developed much faster and more inexpensively than new modern drugs. ${ }^{43}$ This is because their use, preparation, and safety is already understood in traditional knowledge systems, and so preclinical development can be greatly accelerated. World Health Organization (WHO) guidelines ${ }^{45}$ state: "If the product has been traditionally used without demonstrated harm, no specific restrictive regulatory action should be undertaken unless new evidence demands a revised risk-benefit assessment." WHO maintains the position that there is no requirement for preclinical toxicity testing, but rather that evidence of traditional use or recent clinical experience is sufficient. ${ }^{46}$ This is reflected in the Malian regulations, which only require toxicology and clinical trials for extracts, not for crude traditional preparations (Table 2).

The second advantage is that the end product is more widely available and affordable to patients in resource-poor settings than many pharmaceuticals are. MTAs are now considered part of the essential drugs list in Mali. ${ }^{5}$ In terms 
of sales, the most successful have been Balembo, Gastrosédal, and Hépatisane, because there is no affordable conventional equivalent for the treatment of jaundice or hepatitis. The least successful has been Malarial, probably in part because it was more expensive than chloroquine, which until recently was the recommended first-line treatment for malaria, and because it was not perceived as effective by most prescribers. ${ }^{9}$ This emphasizes the need for a new MTA for malaria, which is currently being developed. ${ }^{40-43}$

The third advantage, which is the most important for prescribers and patients, is that they perceive most MTAs to be effective. This was the main reason for choosing to prescribe them as mentioned by $85 \%$ of health workers surveyed in Kadiolo district. ${ }^{8}$ Interestingly, only $38 \%$ of prescribers and $29 \%$ of patients quoted the lower price as their primary reason for choosing to use MTAs. The most popular MTAs with prescribers were Gastrosédal and Laxa-cassia, and the most popular with patients were Laxa-cassia and Hépatisane..$^{8}$ Medical students are taught about MTAs during their training, and the Department of Traditional Medicine has conducted training for doctors on the prescription of MTAs. In general it seems that practicing doctors only prescribe MTAs if they have received an additional training session. As in other parts of the world, it seems that some patients and doctors integrate traditional and modern medicines according to their perceived effectiveness.

One disadvantage of the production of standardized phytomedicines (as opposed to teaching people to grow and produce their own herbal medicines) is that their distribution is hindered by infrastructure problems, which also affect the distribution of conventional medicines. In the survey in Kadiolo district, MTAs were out of stock on an average of 78 days per year $\left(21 \%\right.$ of the time). ${ }^{8}$ However, the two approaches are not mutually exclusive, and the existence of a government-approved MTA legitimizes the approach of certain nongovernmental organizations to teach people how to grow and produce herbal medicines themselves. ${ }^{10}$

Research on MTAs has been constrained by limited financial resources and the need to strengthen research capacity. In particular, many of the clinical trials have been small, uncontrolled, and have remained unpublished. The Multidisciplinary University Traditional Health Initiative (MUTHI), a recently accepted European Union-funded project, is now attempting to contribute to redress this problem by providing training in both nonclinical and clinical aspects of developing improved phytomedicines. It is hoped that better clinical trials will be conducted and more MTAs will be developed as a result, both in Mali and in other African countries.

\section{Acknowledgments}

We thank Dr. Jacques Falquet for useful comments on this article. Some of the time used to prepare this article was funded by the European Union Research Directorate through the MUTHI project, FP7 Grant Agreement No.: 266005.

\section{Disclosure Statement}

Three of the authors (RS, CD, and DD) are employed by the Département de Médecine Traditionnelle, which produces the Improved Traditional Medicines in Mali. The other authors have no financial conflict of interest.

\section{References}

1. Maiga Z, Toure O. Ministerial Order of 20th September 2005, Determining Ways of Applying for Marketing Authorization of Human and Veterinary Medicines [05-2203/MSMEP-SG, in French]. Bamako, Mali: Ministry of Health, Ministry of Farming and Fishing, 2005.

2. National Therapeutic Formulary [in French]. Bamako: Ministry of Health, Elderly People and Solidarity, 1998.

3. Maiga A, Malterud KE, Diallo D, Paulsen BS. Antioxidant and 15-lipoxygenase inhibitory activities of the Malian medicinal plants Diospyros abyssinica (Hiern) F. White (Ebenaceae), Lannea velutina A. Rich (Anacardiaceae) and Crossopteryx febrifuga (Afzel) Benth. (Rubiaceae). J Ethnopharmacol 2006;104:132-137.

4. Occhiuto F, Sanogo R, Germano MP, et al. Effects of some Malian medicinal plants on the respiratory tract of guineapigs. J Pharmacy Pharmacol 1999;51:1299-1303.

5. Diallo D, Paulsen BS, Hveem B. Products of traditional medicine. In: Berge G, Diallo D, Hveem B, eds. Wild Plants of the Malian Sahel [in French]. Paris: Editions Karthala, 2005:135-141.

6. Sutovska M, Franova S, Priseznakova L, et al. Antitussive activity of polysaccharides isolated from the Malian medicinal plants. Int J Biol Macromol 2009;44:236-239.

7. Sanogo R, Germano MP, de Tommasi N, et al. Vernoniosides and an androstane glycoside from Vernonia kotschyana. Phytochemistry 1998;47:73-78.

8. Diallo D, Diakité C, Diawara A, et al. Study of the consumption of the improved traditional phytomedicines in the health district of Kadiolo (region of Sikasso, Mali). Mali Méd 2010;25:5-13.

9. Neuwinger HD. African Ethnobotany: Poisons and Drugs. London: Chapman \& Hall, 1996.

10. Hirt H, M'Pia B. Natural Medicine in the Tropics I: Foundation Text. Winnenden, Germany: Anamed, 2008.

11. Adjanohoun EJ, Ake Assi L, et al. Traditional Medicine and Pharmacopoeia: Contribution to Ethnobotanical and Floristic Studies in Mali [in French]. Paris: Agence de Coopération Culturelle et Technique, 1981.

12. Tona L, Kambu K, Ngimbi N, et al. Antiamoebic and phytochemical screening of some Congolese medicinal plants. J Ethnopharmacol 1998;61:57-65.

13. Sudhakar M, Rao CV, Rao PM, et al. Antimicrobial activity of Caesalpinia pulcherrima, Euphorbia hirta and Asystasia gangeticum. Fitoterapia 2006;77:378-380.

14. Vlietinck AJ, Van Hoof L, Totte J, et al. Screening of hundred Rwandese medicinal plants for antimicrobial and antiviral properties. J Ethnopharmacol 1995;46:31-47.

15. Ogbulie JN, Ogueke CC, Okoli IC, Anyanwu BN. Antibacterial activities and toxicological potentials of crude ethanolic extracts of Euphorbia hirta. African J Biotechnol 2007;6:1544-1548.

16. Galvez J, Crespo ME, Jimenez J, et al. Antidiarrhoeic activity of quercitrin in mice and rats. J Pharm Pharmacol 1993;45:157-159.

17. Dhar ML, Dhar MM, Dhawan BN, et al. Screening of Indian plants for biological activity: Part I. Indian J Exp Biol 1968; 6:232-247.

18. Hore SK, Ahuja V, Mehta G, et al. Effect of aqueous Euphorbia hirta leaf extract on gastrointestinal motility. Fitoterapia 2006;77:35-38.

19. Ridet J, Chartol A. Les proprietes antidysenteriques de l'Euphorbia hirta. Med Trop 1964;24:119-143. 
20. Ito $Y$, Tokuda H, Ohigashi H, Koshimizu K. Distribution and characterization of environmental promoter substances as assayed by synergistic Epstein-Barr virus-activating system. In: Fujiki $\mathrm{H}$, ed. Cellular Interactions by Environmental Tumor Promoters. Tokyo: Japan Science Society Press, 1984.

21. Duez P, Livaditis A, Guissou PI, et al. Use of an Amoeba proteus model for in vitro cytotoxicity testing in phytochemical research: Application to Euphorbia hirta extracts. J Ethnopharmacol 1991;34:235-246.

22. Martin M, Ridet J, Chartol A, et al. Therapeutic action of the extract of Euphorbia hirta in intestinal amoebiasis [in French]. Médecine Tropicale 1964;24:250-261.

23. Pousset J-L. Medicinal Plants of Africa [in French]. Aix-enProvence, France: Edisud, 2004.

24. Nergard CS, Diallo D, Michaelsen TE, et al. Isolation, partial characterisation and immunomodulating activities of polysaccharides from Vernonia kotschyana Sch. Bip. ex Walp. J Ethnopharmacol. 2004;91:141-152.

25. Sanogo R, Giani S, Braca A, et al. Pharmacochemical investigation on some Malian medicinal plants. Curr Topics Phytochem 2002;5:225-234.

26. Nergard CS, Matsumoto T, Inngjerdingen $M$, et al. Structural and immunological studies of a pectin and a pectic arabinogalactan from Vernonia kotschyana Sch. Bip. ex Walp. (Asteraceae). Carbohydr Res 2005;340:115-130.

27. Sanogo R, De Pasquale R, Germano MP, et al. Vernonia kotschyana Sch. Bip.: Tolerability and gastroprotective activity. Phytother Res 1996;10(suppl):S169-S171.

28. Diallo D, Coumaré A, Koita N. Preliminary study of a Malian medicinal plant: Vernonia kotschyana (Sch. Bip) [in French]. Cahier spécial de l' INRSP 1990;1:52-56.

29. Arbonnier M. Trees, Shrubs and Lianas of the Dry Zones of West Africa [in French]. Paris: CIRAD, Museum National d'Histoire Naturelle, 2002.

30. Kazmi MH, Malik A, Hameed S, et al. An anthraquinone derivative from Cassia italica. Phytochemistry 1994;36:761-763.

31. Heinrich M, Barnes J, Gibbons S, Williamson EM. Fundamentals of Pharmacognosy and Phytotherapy. Edinburgh: Churchill Livingstone, 2004.

32. Diallo D, Maiga A, Diakite C, Willcox M. Malarial-5: Development of an antimalarial phytomedicine in Mali. In: Willcox M, Bodeker G, Rasoanaivo P, eds. Traditional Medicinal Plants and Malaria. Boca Raton: CRC Press, 2004.

33. Iwalewa EO, Lege-Oguntoye L, Rai PP, et al. In vitro antimalarial activity of leaf extracts of Cassia occidentalis and Guiera senegalensis in Plasmodium yoelii nigeriensis. West Afr J Pharmac Drug Res 1990;9(suppl):19-21.

34. Kerharo J, Adam JG. La Pharmacopée Sénégalaise Traditionnelle: Plantes Médicinales et Toxiques. Paris: Vigot Frères, 1974.

35. Jellal A, Lemerre $S$, Michot $P$, et al. Spilanthes [in French]. Dijon: Etablissement National d'Enseignement Supérieur Agronomique (ENESA). 1998
36. Gasquet M, Delmas F, Timon-David P, et al. Evaluation in vitro and in vivo of traditional antimalarial, "Malarial 5". Fitoterapia 1993;64:423-426.

37. Koita N. A comparative study of the traditional remedy "Suma-Kala" and chloroquine as treatment for malaria in the rural areas. In: Mshigeni KE, Nkunya MHH, Fupi V, et al. eds. Proceedings of an International Conference of Experts from Developing Countries on Traditional Medicinal Plants. Arusha, Tanzania: Dar Es Salaam University Press, 1990:68-82.

38. Kéita A, Doumbo O, Koïta N, et al. Experimental research on a traditional antimalarial: Preliminary study on the feasibility of a clinical trial protocol [in French]. Bulletin de Médecine Traditionnelle et Pharmacopée 1990;4:139-146.

39. Diallo D, Graz B, Falquet J, et al. Malaria treatment in remote areas of Mali: Use of modern and traditional medicines, patient outcome. Trans R Soc Trop Med Hyg 2006;100: 515-520.

40. Willcox ML, Graz B, Falquet J, et al. Argemone mexicana decoction for the treatment of uncomplicated falciparum malaria. Trans R Soc Trop Med Hyg 2007; 101:1190-1198.

41. Graz B, Willcox M, Diakite C, et al. Argemone mexicana decoction versus Artesunate/Amodiaquine for the homebased management of malaria in Mali: Policy and public health implications. Trans R Soc Trop Med Hyg 2010;104: 33-41.

42. Willcox ML, Graz B, Diakite C, et al. Is parasite clearance clinically important after malaria treatment in a high transmission area? A 3-month follow-up of home-based management with herbal medicine or ACT. Trans R Soc Trop Med Hyg 2011;105:23-31.

43. Willcox ML, Graz B, Falquet J, et al. A "reverse pharmacology" approach for developing an antimalarial phytomedicine. Malar J 2011;10(suppl 1):S8.

44. Ahua KM, Ioset JR, Ioset KN, et al. Antileishmanial activities associated with plants used in the Malian traditional medicine. J Ethnopharmacol 2007;110:99-104.

45. WHO. Expert Committee on Specifications for Pharmaceutical Preparations: Thirty-Fourth Report. Geneva: World Health Organisation, 1996.

46. WHO. Guidelines for the Appropriate Use of Herbal Medicines. Manila: WHO Regional Office for the Western Pacific, 1998.

Address correspondence to: Merlin Willcox, BA, BM, BCh, MRCGP Department of Primary Health Care University of Oxford 23-38 Hythe Bridge Street Oxford OX1 2EP United Kingdom

E-mail: merlin.willcox@phc.ox.ac.uk 